\title{
Phenolic Compounds: Health Effects and Its Removal From Aqueous Environments by Low Cost Adsorbents
}

\author{
Edris Bazrafshan ${ }^{1,}$, Ferdos Kord Mostafapour ${ }^{1}$, Hossein Jafari Mansourian ${ }^{1}$ \\ ${ }^{1}$ Health Promotion Research Center, Zahedan University of Medical Sciences, Zahedan, IR Iran \\ * Corresponding author: Edris Bazrafshan, Health Promotion Research Center, Zahedan University of Medical Sciences, Zahedan, IR Iran. Tel.: +98-5412425375, Fax: +98-5412425375, \\ E-mail: ed_bazrafshan@yahoo.com
}

Received: Jun 17, 2013; Revised: July 03, 2013; Accepted: July 06, 2013

Keywords: Phenol; Adsorption; Wastewater

Phenols are natural products originated by various plants and animals decomposition. Also, phenolic compounds, as a class of organic materials, have a similar structure to the more common pesticides which are commonly resistant to biological degradation. In addition, phenol is one of the most general pollutants in effluents discharged from diverse industries producing various products including resins, plastics, adhesives, iron, steel, aluminum, leather, etc. Additionally, phenol is used as a solvent, as an antiseptic and as an additive in disinfectants $(1,2)$. These industries are distributed in wide area, which result in severe environmental troubles because of their toxicity low biodegradability and their ability to build up potential in plants and tissues, such as fish which live in the lakes and streams polluted with phenolic compounds have a revolting astonishing flavor and very bad smell. Consequently, the effluents containing phenol and its derivatives must be treated prior to their release into water resources.

Furthermore, phenol is a combustible compound that is extremely soluble in water, oil and numerous organic solvents. It is characterized by a representative sharp sweet, medical, or tar like smell (3). In addition, in the presence of chlorine in water, phenol forms chlorophenol, which has a medical flavor, which is completely manifest and unpleasant. Also, phenol is a troublesome contaminant that contributes to off flavors in food processing waters. Presence of phenol in water resources can result in the reduction of water quality, decease of aquatic organisms and also prohibition of the common acts of biological community (4). Almost the entire phenols are toxic and some are known as carcinogen for human. These compounds are incorporated in the food chain and cause significant environmental troubles. Owing to their toxic effects, including permeabilization of cellular and cytoplasmic coagulation and also irritation to skin, phenolic compounds can injure sensitive cells and consequently cause profound health and environmental issues $(5,6)$. On the other hand, acute poisoning can cause strict gastrointestinal disturbances, kidney malfunction, and circulatory system failure and also lung edema. Deadly doses can be absorbed through the skin. Key organs injured by chronic exposure to phenol consist of spleen, pancreas and kidneys (7). Therefore, phenol and its compounds are grouped as priority pollutants by the United States of environmental protection agency (USEPA), which take the 11th place under the 129 chemicals with a discharge limit of lower to $1 \mathrm{mg} / \mathrm{L}$ in the treated effluent in order to human health protection from the possible toxic effects caused by exposure to phenol (8). In Iran, a maximum phenol level of $1.0 \mathrm{mg} / \mathrm{L}$ is permitted in wastewater for discharge to surface water resources by the Institute of Standard and Industrial Research of Iran (ISIRI). Wastewaters containing phenols and other toxic compounds require careful treatment before release into the receiving water sources. Dutta et al. (9) classified the treatment processes of phenolic effluents into two main categories: destructive process such as destructive oxidation with $\mathrm{O} 3, \mathrm{H} 2 \mathrm{O} 2$, or manganese oxides, and recuperative processes such as adsorption and membrane separation. Adsorption process is presently being used broadly for organic and inorganic micropollutants removal from aqueous environments (3). This procedure is the easiest, the fastest, the most efficient and cost-effective option for removal of phenolic compounds. Among different materials, activated carbon has high affinity to phenolic compounds. Nevertheless, the high cost of activated carbon has stimulated interest in investigating the possibility of

Implication for health policy/practice/research/medical education:

The content of this article is useful for environmental health managers and also for industrial waste managers for efficient treatment of industrial wastewaters.

Copyright $\odot 2013$, Health Promotion Research Center.This is an Open Access article distributed under the terms of the Creative Commons Attribution License (http:// creativecommons.org/licenses/by/3.0), which permits unrestricted use, distribution, and reproduction in any medium, provided the original work is properly cited. 
using low cost adsorbents. Substitute materials experienced consist of straw, automobile tires, fly ash, coal reject, biosolids, pistachio nut shell ash, palm seed coat, fertilizer waste and sawdust $(3,6,10)$. Moreover, because of the high cost and unpredictable performance of carbon regeneration, single use materials are more attractive. In a study that was performed by Bazrafshan et al. on phenol removal from aqueous environments by pistachio nut shell ash as a low cost adsorbent, the result was follows: maximum adsorption capacity $327.6 \mathrm{mg} / \mathrm{L}$ (98.28\% removal efficiency) at pH 5, initial concentration of $100 \mathrm{mg} / \mathrm{L}$ and $25 \pm 2^{\circ} \mathrm{C}(10)$. Nonetheless, it must be mentioned that the choice of activated carbon precursor mainly depends on its availability, price and purity, but the manufacturing process and planned applications of the product are also imperative considerations (4, 6). Agricultural wastebased carbon has the benefit of exhibiting little ash content, reasonable hardness and high surface area and/or sufficient porous structures $(6,10)$. Consequently assessment of diverse materials is getting increased attention in all over the world as it is renewable, extensively available, inexpensive, and environmental friendly.

\section{Acknowledgements}

The authors would like to express their thanks to the colleagues of faculty of health.

\section{Authors' Contribution}

Conceived and designed the manuscript: Edris Bazrafshan, Ferdos Kord Mostafapour, Hossein. Jafari Mansoorian, Wrote the paper: E. Bazrafshan.

\section{Financial Disclosure}

This article doesn't have financial disclosure.

\section{Funding/Support}

This article doesn't have funding/support.

\section{References}

1. Girelli AM, Mattei E, Messina A. Phenols removal by immobilized tyrosinase reactor in on-line high performance liquid chromatography. Anal Chim Acta. 2006;580(2):271-7.

2. Pan G, Kurumada KI. Hybrid gel reinforced with coating layer for removal of phenol from aqueous solution. Chemical Engineering Journal. 2008;138(1):194-9.

3. Ahmaruzzaman M. Adsorption of phenolic compounds on low-cost adsorbents: A review. Adv Colloid Interface Sci. 2008;143(1-2):48-67.

4. Lin K, Pan J, Chen Y, Cheng R, Xu X. Study the adsorption of phenol from aqueous solution on hydroxyapatite nanopowders. J Hazard Mater. 2009;161(1):231-40.

5. Gomez JL, Bodalo A, Gomez E, Bastida J, Hidalgo AM, Gomez M. Immobilization of peroxidases on glass beads: an improved alternative for phenol removal. Enzyme and microbial technology. 2006;39(5):1016-22.

6. Rengaraj S, Moon SH, Sivabalan R, Arabindoo B, Murugesan V. Removal of phenol from aqueous solution and resin manufacturing industry wastewater using an agricultural waste: rubber seed coat.J Hazard Mater. 2002;89(2-3):185-96.

7. Agency for Toxic Substances and Disease Regis-try (ATSDR). Toxicological profile for Phenol. Atlante, GA: US: Public Health Service; 2006

8. Tor A, Cengeloglu Y, Aydin ME, Ersoz M. Removal of phenol from aqueous phase by using neutralized red mud. J Colloid Interface Sci. 2006;300(2):498-503.

9. Dutta NN, Borthakur S, Baruah R. A novel process for recovery of phenol from alkaline wastewater: laboratory study and predesign cost estimate. Water environment research. 1998;70(1):4-9.

10. Bazrafshan E, Kord Mostafapour F, Mahvi AH. Phenol removal from aqueous solutions using Pistachio-nut shell ash as a low cost adsorbent. Fresen Environ Bull. 2012;21(10):2962-8. 